\title{
Campaigning Online and Offline: The use of YouTube Movie in the Movement Against Environmental Destruction in the Movie "Samin vs Semen"
}

\author{
Wijayanto $^{1}$, Hendra Try Ardianto ${ }^{2}$, Esther Sri Astuti S. A. ${ }^{3}$ \\ \{wijabaru@gmail.com ${ }^{1}$ \} \\ Universitas Diponegoro, Indonesia ${ }^{1,2,3}$
}

\begin{abstract}
This paper examines the use of movie uploaded in the YouTube channel (YouTube's movie) as an instrument for campaign against environmental destruction in the case of movie entitled Samin vs Semen. As a method, this study combined discourse analysis of the movie, content analysis of the YouTube's comments and in-depth interviews with the CSO's activists. The research found as follows: first of all, the movie framed the people of Samin as the defender of environmental protection in Kendeng mountains. Meanwhile, the concrete factory was framed as the perpetrator of environmental destruction in Kendeng area. Thus, conflict between the people of Samin and the concrete factory was framed as the conflict between the good and the evil. Second, the uploaded movie has been viewed hundred thousand of times by the citizens, liked by thousands and commented by hundred. The YouTube has raised the awareness of the citizens about the existence of environmental destruction and the fights against it and has provided the cites for discussion about the issues. Finally, the uploaded movie in YouTube has been used as instrument for international consolidation among the people of Samin, influenced the agenda setting of the national and international media and expanded the movement to protest the concrete factory both on the national and international level.
\end{abstract}

Keywords: Campaign, YouTube, Movie, Environmental Movement, Environmental Destruction.

\section{Introduction}

This research aims to reveal the role of digital media in the movement against the environmental destruction in the case of concrete factory in Kendeng, Rembang. Studies about the use of social media in the social movement or social activism are quite abundant, however those focusing on the environmental issue are still hardly found. This study tries to fill in the gap by taking the case of the use of YouTube channel in the case of the movement against environmental destruction in Kendeng through the development of the concrete factory.

As Indonesia currently undergoes the massive program of infrastructure development under Jokowi's administration, the development of mining company as well as concrete factories have been done in many areas in the country. However, while the massive infrastructure development is being done, the government seems to pay insufficient attention to the environmental impact of the program. In this regard, campaign by civil society elements to raise the government and society's awareness is a very interesting phenomena which 
deserves attention. Civil society organization such as Watcdoc.co has been one of them. It interestingly uses movie and YouTube as an integral part of the movement. However, what the ideology behind the movie is still under studied, not to mention the extent of the impact of the movement to raise awareness and to influence government's policy in this matter.

\section{Research Questions}

Based on the above explanation on research background, this research aims to answer these following questions:

a) What is the dominant discourse presented in the movie Semen vs Samin?

b) How has the YouTube version of the movie helped the campaign against environment destruction online?

c) How has the YouTube version of the movie influenced the movement against the environmental destruction offline?

\section{Method of Data Collection}

In order to answer the question above, this research combines three different method of analysis and data gathering. First of all, it will conduct discourse analysis on the content of the movie and in-depth interview with the activists of Watchdoc.co. Secondly, conduct audience analysis towards the viewers of the movie in the YouTube comments examine the extents in which the movie has raised their awareness on the environmental issues. Thirdly, it conducts in-depth interview the activists who have produced the movie and the underlying motivation behind it.

\section{Literature Review}

Theories on the role of digital activism in politics can be broadly categorized in four main arguments. The first argues that digital activism can be a powerful weapon from the weak or even the ordinary people to fight against the powerful parties and actually win battle against them. This has been made clear in the case of the anti-corruption movement in Indonesia to support the Commission of Corruption Eradication (KPK) from being weakened by the Indonesian police. Furthermore, this has also been made clear in the case of Prita Mulya Sari, an ordinary woman whose child became a victim of a mal practice allegedly committed by a private hospital namely Omni International. In both cases, the internet has been very effective as a tool for ordinary people to gain support from the public in general to fight against power holder, be it political power holder i.e. the police or private power holder i.e. the private hospital [1].

The second argues that the digital activism might not be successful in making the weak conquering the powerful parties, however it has been successful in raising citizen's awareness about the existence of the abuse of power by the power holders. This has been made clear in the case of citizen activism in the social media to inform, discuss and criticize the existing problems of corruption by the local elites in Banten [2]. The case demonstrated that despite 
the dynasty in Banten was too strong to be overthrown from power, at least the public could still express their testimony, disappointment and hostility towards the corruption practice. It was done through the act of witnessing and flaming which are important as the evidence that citizens didn't accept the corrupt behavior.

The third theory was suggested by Tapsell [3] who suggested that the internet could equally make both the ordinary as well as the power holders gains more power. The internet gave a growing number of ordinary people instrument to participate in discussions, shape media content and lobby politicians in order to have their voices heard and bring about the meaningful change. However, it also enabled the power holders became even more powerful with the capital they already have. This is especially found in the case of politico-business oligarchs who have both political and economic power. The Indonesian media conglomerates who are also chairperson or elites in Indonesian political parties are the perfect example of this. Even before the internet arrived, they already own mainstream media in Indonesia starting from print media, radio and television. With the arrival of the internet, they soon crated an internet platform or bought the existing media platform to increase they profit as well as their influence. The fact that possessing online media needed a great amount of money had enabled them maintain their oligarchic power.

Finally, the last theory was suggested by Kurniawan and Rye [4] who suggested that instead of answering the impact of the internet to the "outside world", they suggested to look at the impact of the internet to the structure and dynamic within civil society organization and their activism. They argued that internet did bring impact to the civil society organizations' (CSO) internal dynamics when used by well-established organizations with well-developed international networks to be more professional. They have the financial support to develop separate internal units designated to handle the new communication tools and supply a stable infrastructure accessible for communication both internally as well as externally. On the contrary, less established and more informal CSO's couldn't maximally take benefit from the internet for the advancement of their works. This is because they were also still struggling to find hardware and software that they could use the most.

\section{Result and Discussion}

\subsection{The YouTube Movie: Ideology, Online and Offline Campaign}

\subsubsection{Angel Versus Evil: The Ideology of the Movie}

The film Samin versus Semen is 39.25 minutes long, aka almost 40 minutes. This film was made by a CSO who is active in documenting social problems in Indonesia called Watchdoc. The film was made on a visit of the Watchdoc team to Rembang from the end of January to mid-February 2015 in approximately one month.

In terms of content, this film has an ideology of side to nature preservation and local wisdom of the Samin community in the conflict against the cement factory. This is evident from the title Samin vs Semen. In this regard, this film takes the narration of good versus evil in which the Samin tribe and nature are good while the cement factory and all the apparatus that supports it are positioned as evil who want to exploit nature which is highly valued by the Samin tribe. The narrative of this conflict has emerged since the opening of the film which illustrates the repressive actions carried out by the official to mothers who carried out peaceful 
actions to reject the cement factory. The mothers quietly protested, but the calm was disturbed by the arrival of a man in a white shirt and black hat. He shouted loudly, "Conveying opinions is permissible, but it must comply with the law".

But the gazes of the mothers did not change, remained gentle. The burly man continued,

"On behalf of the law...if mothers block it like this, I will put you (in prison),"

Then the police began their action, breaking their silence and silence. A mother with a pink kebaya was appointed. But that did not make the other mothers' partners budge, they remained seated, and blocked the road. Sit quietly. This section clearly displays the narrative of how elderly women who are elderly as weak women are treated repressively by men and security officials. It is easy to make the public sympathize with them and criticize the authorities.

From this section, it can be seen that this film has a partiality on sustainability and opposes exploitation by cement factories. Concrete manifestation of the partisanship, the film frames the factory as evil and nature and its defenders as good. In the next section, we will discuss how the impact of YouTube is on CSO's movement against environmental damage.

\subsubsection{YouTube Movie as an Instrument for Online Campaign}

YouTube is a platform that enables us for not only up loading a video but also traced the number of viewers of it. Since being uploaded on YouTube on March 3, 2015, this film has been watched hundreds of thousands of times and received thousands of likes as seen in the picture 1 .

Picture 1. The Number of Views and Likes (YouTube Samin vs Semen)

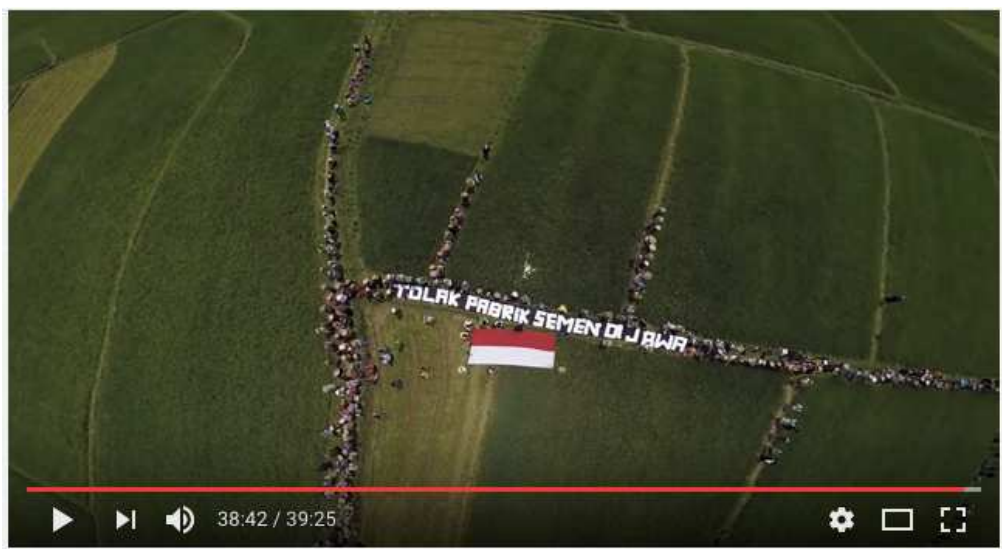

SAMIN vs SEMEN (full movie)

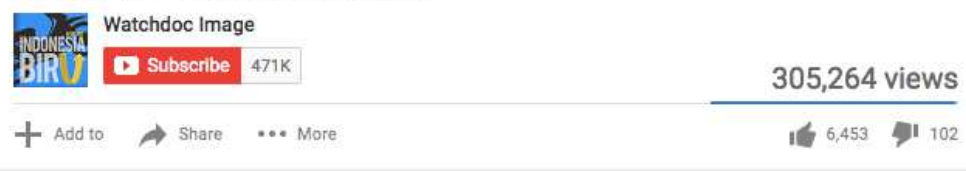


From the picture above, we can see the number of views of the movie in the YouTube which has reached 309.668 times (as per 6 February 2020). It can also be seen that there are 6.533 likes to the movie (at the same date). It is a much huger number compared to those who don't like it which is only 102 viewers.

Meanwhile, what unique on YouTube is that it also enables interaction to the viewers of the video. This is because people can also comment to the video that we have posted. In this regard, there are hundreds of comments to the movie on YouTube as can be seen in the picture 2.

Picture 2. Number of Comment

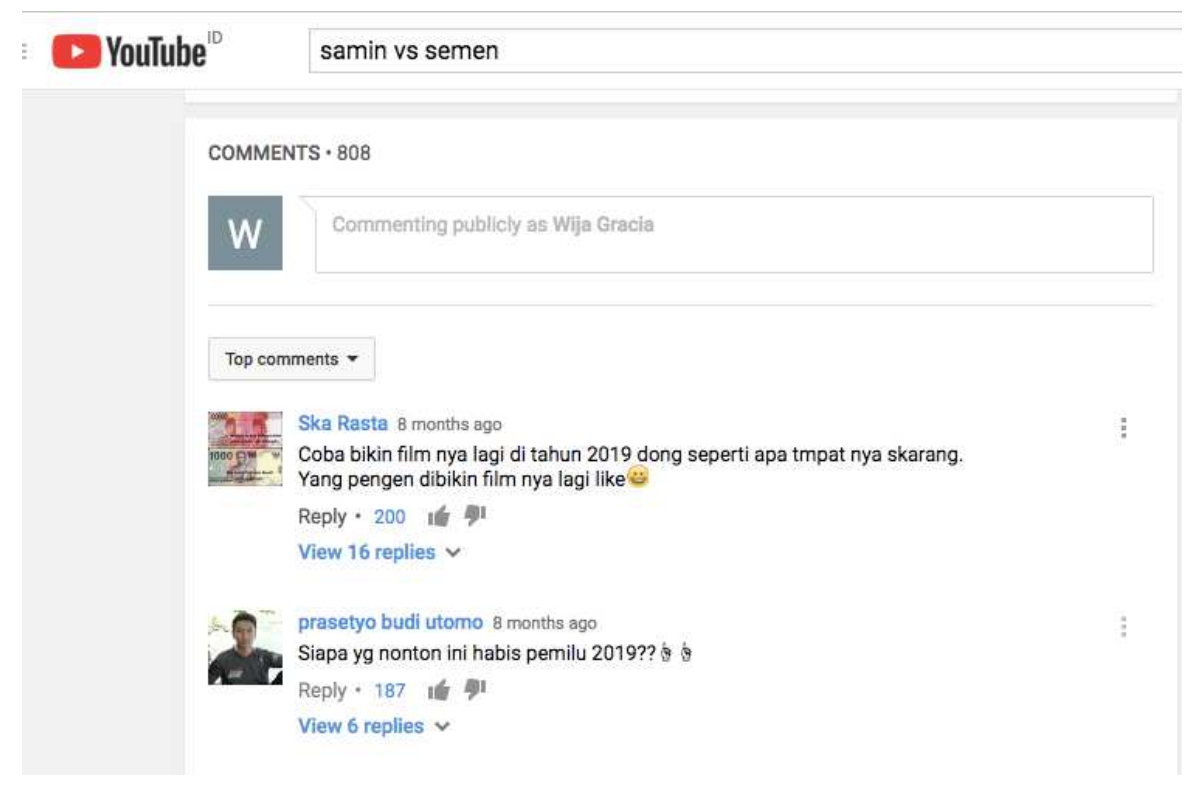

From the picture above, it can be seen that there are more than 800 people commented to the movie. This means that people are attracted to the video and eager to participate by commenting to it. Furthermore, the picture above also shows that people are supporting the creation of the movie and suggesting the producer to create the sequel of the movie for capturing the recent up date of the place where the video was taken. It can be seen from the account namely Ska Rasta above who wrote as follows:

"Please make another movie as the sequel of this one and let's see how this place looks like now. Those who agree with me, please like my comments."

The comment doesn't only give a suggestion to produce the sequel but also asked other viewers to support his idea. He said those who agree with him to like his comments. As can be seen in the picture 2, his comments are indeed liked by 200 people and generate 16 replies creating an on line discussion. We can see it in the picture 3. 
Picture 3. Online Discussion (Comments and Replies)

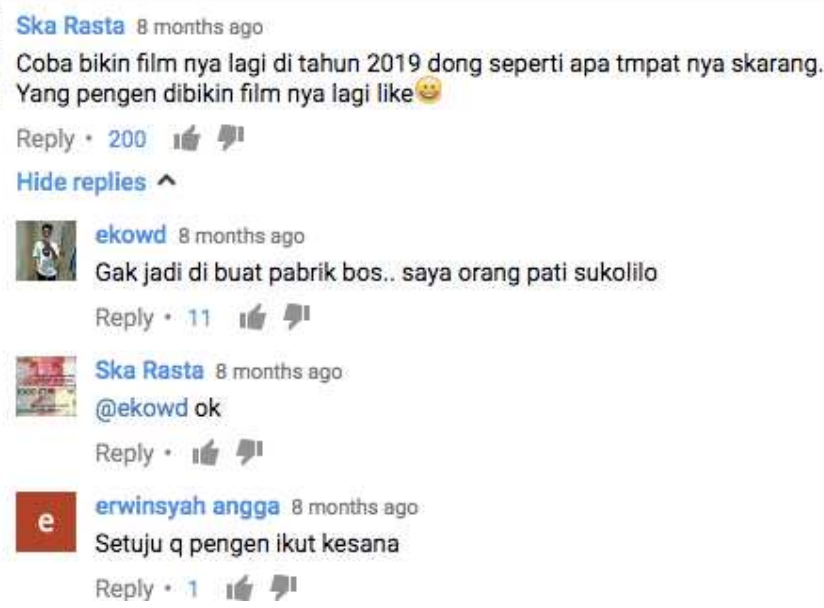

From the picture 3 above, we can see 2 out of 16 replies to the comment. One account in the name of Ekowd said that the establishment of the factory was cancelled. He claimed that he lives in Pati near to the factory. His replied perhaps didn't necessarily agree to the idea. However, it reflected that a discussion was going on. Another account namely Erwinsyah Angga suggested that he agreed to the idea and wanted to go to the place where the movie was taken too.

The uploaded movie in the YouTube also helped raised people's awareness about the existence of the environmental destruction by the concrete factory. It can be seen from the following comment:

Picture 4. Raising Awareness 1

Pemuda Muslim 2 years ago

TOLAK PABRIK SEMEN DI KABUPATEN PATI. Terimakasih sudah nembuat film dokumenter ini sehingga membuka mata kami.

Reply $\cdot 9$

In the picture 4, an account which name itself as Pemuda Muslim wrote a comment as follows:

"Reject the founding of concrete factory in Pati regency. Thank you for making this documentary movie that has opened our eyes."

This voluntarily comment reflected that he was really moved by the movie. The same line of testimony was also expressed by another account namely Putu Steven Mandra as follows: 
Picture 5. Raising Awareness 2

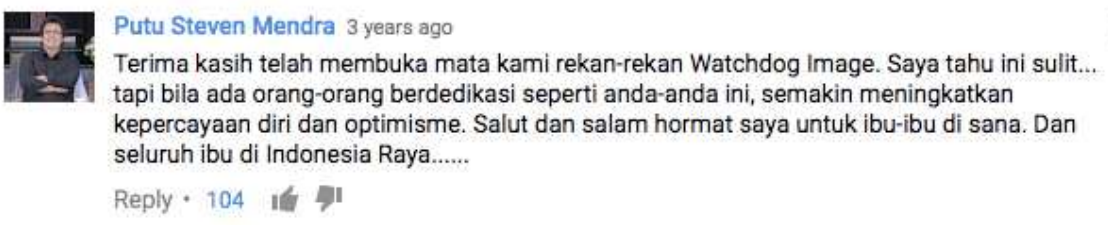

In picture 5 above, he wrote a comment as follows:

"Thank you for opening pour eyes my dear friend in Watchdoc. I know it's difficult...but if there are more dedicated people like you, it gave confidence and optimism. Salute and respect for the women in there (who protested the factory), and to all women in Indonesia..."

From the picture above it is clear how the movie uploaded in you tube has helped them aware about the existence of struggle against the factory as well as the protest against it by the women in Kendeng.

From the description above it can be seen that the film uploaded on YouTube can be an instrument for the campaign against environmental damage in social media where many people watch, give likes, share comments to discuss the contents of the film and become aware of environmental damage and who becomes the culprit behind the damage. In the next section, it will be explained how movies uploaded on YouTube can be a tool for conducting off-line campaigns in the real world.

\subsubsection{YouTube Movie as an Instrument for Offline Campaign}

As an instrument for the campaign against environmental destruction in the real world, this film has at least three functions. First, this is to build the solidity of the movement among the Samin community itself to refuse the factory. As revealed by Dandhy, the founder of Watchdoc, he uploaded the movie to YouTube so that the people watching the Kendeng both in Pati and in Rembang immediately watched. So, the initial intention was very inward for their movement.

Second, the movie functions as a venue for campaigns to influence the media and policy agenda. Because this film has many viewers, mainstream media journalists make this as their agenda setting. This is one of the reasons why Tempo magazine interviewing the Governor of Central Java province, Ganjar Pranowo. In this case, Ganjar commented. He said even the Samin people themselves did not like the movie. This statement was actually denied by the Samin people themselves, namely: Gunretno who actually said he gave permission to Dandhy.

The next moment on the media agenda was when 2016-2017 the Kendeng women demonstrated to put their feet in front of the palace. It became a national headline. These are Rembang people.

"Now this news is strong. But people do not know. Then people then look for this film. The media wrote this news with reference to this film to attract people's attention", (Interview with Dandhy Dwi Laksnono, 30 July 2019). 
Third, the film gives the environmental movement against Samin has greater strength. Mas Gunretono and Ms. Gunarti. Mas Gun experienced firsthand how people from various regions supported them. They got a phone call from many different places. The movement was then more confidence. It could hold a national grip.

Fourth, the film also influences the international news and environmental movement agenda. As soon as that got exposure in the 2016, international attention began to emerge. Because Indocement is in German Hedelberg, there is a foot cement demonstration there too. They played the movies and Gunarti, one of the Samin' protesters, was even brought to Germany. What was displayed was a screenshot from YouTube. The film was made roadshow in 10 cities in Germany, among others: Berlin, Hamburg, Freiburg, Leipzig, Koln and Hedelberg. The climax was when Der Spiegel then wrote one special thing. Then TV2 in Germany aired it. And they asked Dandhy to make a new film about this but with their tools.

\section{Conclusion}

This paper analyzes the role of films uploaded on YouTube in the movement against environmental damage in the case of the film Samin versus Semen produced by watchdoc.co. From the studies conducted, it can be found that the films uploaded on YouTube can be a means to campaign against environmental damage both online and off line. The contents of the film clearly carry the ideology in favor of environmental preservation and community movements that struggle to fight against cement companies trying to establish cement factories which are considered harmful to the environment. In this case, the Samin residents who fought against the cement were narrated as the good party who were victims of the evil cement factory. This film uses the narrative of good versus evil as available in Hollywood style to attract sympathy and inspire the public at large to fight.

Uploading this movie on YouTube also turned out to be a successful media for social media campaigns. Since being uploaded, this film has been watched hundreds of thousands of times, liked by thousands of people and commented on by hundreds of people. These people also interact with and discuss on this YouTube page. This film has also succeeded in opening the eyes of citizens about the existence of environmental destruction by a cement factory which at first, they did not know. Here, YouTube has become a platform that allows the interaction between citizens with features: views, likes and comments.

Finally, this film can also be an instrument for CSO's in this case Samin Citizens to carry out internal consolidation and external campaigns. Internally, this film on YouTube has become an arena to build solidity among themselves. This also gave enthusiasm and confidence to the residents of Samin. Externally, this YouTube movie has succeeded in influencing the media agenda and public policy agenda. From the media side, the media reported this cement case with reference to film. What became the media agenda then became the public policy agenda as evidenced by the response from the governor even though the response was negative. This film has even succeeded in finding its echo abroad, where it was an inspiration for the broader movement in Germany, where one of the cement factories is located.

\section{References}

[1] M. Lim, "Many Clicks but Little Sticks: Social Media Activism in Indonesia," J. Contemp. Asia, 
vol. 43, no. 4, pp. 636-657, 2013.

[2] M. Z. Fauzanafi, "Searching for digital citizenship: Fighting corruption in Banten, Indonesia," Austrian J. South-East Asian Stud., vol. 9, no. 2, pp. 289-294, 2016.

[3] R. Tapsell, Media power in Indonesia: Oligarchs, citizens and the digital revolution. Rowman \& Littlefield International, 2017.

[4] N. I. Kurniawan and S. A. Rye, "Online environmental activism and Internet use in the Indonesian environmental movement," Inf. Dev., vol. 30, no. 3, pp. 200-212, 2014. 